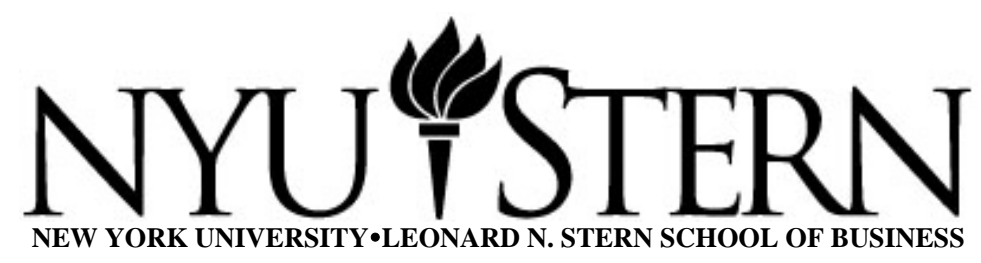

Department of Finance

Working Paper Series

FIN-03-007

Issues in the Credit Risk Modeling of Retail Markets

Linda Allen, Gayle DeLong and Anthony Saunders

February 2003

The 2003 NYU Stern Department of Finance Working Paper Series is generously sponsored by

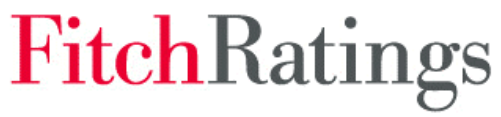




\title{
Issues in the Credit Risk Modeling of Retail Markets
}

\author{
Linda Allen \\ Professor of Finance \\ Zicklin School of Business, Baruch College, CUNY \\ Linda_Allen@baruch.cuny.edu \\ Gayle DeLong \\ Assistant Professor of Finance \\ Zicklin School of Business, Baruch College, CUNY \\ Gayle_DeLong@baruch.cuny.edu \\ Anthony Saunders \\ John M. Schiff Professor of Finance \\ Stern School of Business, New York University
}

ASaunder@stern.nyu.edu

February 2003

\begin{abstract}
$\underline{\text { Abstract }}$
Retail loan markets create special challenges for credit risk assessment. Borrowers tend to be informationally opaque and borrow relatively infrequently. Retail loans are illiquid and do not trade in secondary markets. For these reasons, historical credit databases are usually not available for retail loans. Moreover, even when data are available, retail loan values are small in absolute terms and therefore application of sophisticated modeling is usually not cost effective on an individual loan-by-loan basis. These features of retail lending have led to the development of techniques that rely on portfolio aggregation in order to measure retail credit risk exposure. BIS proposals for the Basel New Capital Accord differentiate portfolios of mortgage loans from revolving credit loan portfolios from other retail loan portfolios in assessing the bank's minimum capital requirement. We survey the most recent BIS proposals for the credit risk measurement of retail credits in capital regulations. We also describe the recent trend away from relationship lending toward transactional lending, even in the small business loan arena traditionally characterized by small banks extending relationship loans to small businesses. These trends create the opportunity to adopt more analytical, data-based approaches to credit risk measurement. We survey proprietary credit scoring models (such as Fair, Isaac and SMEloan), as well as options-theoretic structural models (such as KMV and Moody's RiskCalc) and reduced form models (such as Credit Risk Plus).
\end{abstract}




\section{Issues in the Credit Risk Modeling of Retail Markets}

\section{Introduction}

Retail credit markets offer special challenges to practitioners, regulators and academics alike. Because of the special features of the retail market, one cannot analyze small, retail loans by simply downsizing the models used to analyze large, wholesale loans. The retail credit market provides funds to small, typically unrated borrowers. The relatively small size of each loan implies that the absolute size of the credit risk on any individual loan is minimal. Losses on any single retail loan will not cause a bank to become insolvent. Thus, the cost per loan of determining the credit risk of retail loans is often greater than the benefit in terms of loss avoidance, and ascertaining the credit risk on an individual retail loan basis may not be worthwhile. Moreover, the propensity to default or become delinquent may be affected by social factors, as well as standard economic and business cycle effects. Gross and Souleles (2002) find that retail borrowers were increasingly willing to default on their credit card debt between 1995 and 1997 due in large part to the falling social, information, and legal costs of default.

The wholesale market, on the other hand, deals with large, negotiated loans to borrowers who often have credit ratings. These large loans often are syndicated; thereby creating a secondary market which does not exist for retail bank loans. Loan prices are available for syndicated loans trading in the secondary market. ${ }^{\square}$ In contrast, retail loans are not frequently traded so there is no history of daily price fluctuations upon which to build future price or value expectations. Risk characteristics such as the probability of

\footnotetext{
${ }^{1}$ For example, Loan Pricing Corporation maintains a database that marks to market approximately 2,000 syndicated bank loans on a daily basis using dealer bid/ask quotes.
} 
default (PD), the loss given default (LGD) and default correlations differ from wholesale commercial loan markets so that the parameters used for wholesale loan markets cannot be used reliably for retail markets; see Risk Management Association (RMA) (2000). Although several models exist to guide the providers of wholesale loans, ${ }^{2}$ the body of research on retail credit risk measurement is quite sparse. A survey of what we know, and perhaps more importantly, what we don't know in the area of retail credit risk measurement is the topic of this paper.

In this paper, we examine credit risk at the retail level. In Section 2, we begin with an overview of the proposals from the Bank for International Settlements (BIS) concerning international bank capital requirements for retail credit. In Section 3, we examine some traditional models of credit risk measurement - expert systems, rating systems and credit scoring. In Section 4, we compare two major approaches to small business lending - relationship lending, which entails significant private information produced by bank monitoring in the context of a long-standing bank-borrower business relationship, as compared to transactional lending, which does not incorporate a significant expenditure of resources by the bank on obtaining private information about the borrower. Each of these forms of retail lending offer unique problems in the measurement of the retail loan's credit risk. For example, it may be more appropriate to measure the credit risk of the entire bank-borrower relationship, rather than concentrating on the stand-alone credit risk of an individual relationship bank loan. In Section 5, we discuss how one may apply new techniques of credit risk measurement to retail loans, and the paper concludes in Section 6.

\footnotetext{
${ }^{2}$ For more comprehensive coverage of the models, see Saunders and Allen (2002).
} 


\section{BIS Basel New Capital Accord}

The Bank for International Settlements (BIS (2001), p. 55) defines retail credit as, "homogeneous portfolios comprising a large number of small, low value loans with either a consumer or business focus, and where the incremental risk of any single exposure is small." These types of loans include loans to individuals such as credit cards, residential mortgages and home equity loans as well as other personal loans such as educational or auto loans. Small business loans could also be included as long as the bank treats these facilities the same way it treats other retail credits.

The proposed Basel New Capital Accords allows banks to choose among several approaches to determine their capital requirements. The Standardized Approach allows less sophisticated banks to use external credit ratings to classify the bank's assets into risk classes. Over time, banks are expected to evolve to the Internal Ratings-Based Approaches (Foundation and Advanced) that rely on the bank's own experience in determining the risk characteristics of various asset classes. For example, the Foundation IRB Approach for corporate, sovereign, and bank exposures allows banks to provide estimates of probability of default, but requires banks to use supervisory estimates of loss given default, exposure at default, and maturity. The Advanced IRB Approach for such exposures allows banks to provide estimates of PD, LGD, and EAD, and requires banks to provide estimates of maturity.

The treatment of small- and medium-sized enterprise (SME) exposures is viewed as especially important in countries where small/medium sized firms comprise a significant component of the industrial sector (e.g. Germany). SME borrowers are defined by the Basel Committee as those with less than $€ 50$ million in annual sales. Such 
exposures are allowed to have up to $20 \%$ lower capital requirements than exposures to larger firms. Furthermore, banks that treat their SME exposures as a homogenous portfolio (in the same way as they treat their retail exposures) are permitted to apply the retail IRB capital requirements to the portfolio as long as the exposure to the bank of any individual SME is less than $€ 1$ million.

Banks opting to use the Standardized Approach for their retail exposures would continue to use the $8 \%$ capital requirement (under the original Basel Capital Accord, which was implemented in 1992) to calculate the minimum capital requirement. However, the risk weights would vary for different classes of retail loans. Specifically: $\mathrm{K}=\mathrm{EAD} \times \mathrm{RW} \times 0.08$

where $\mathrm{K}$ = capital requirement, $\mathrm{EAD}=$ exposure at default of the retail assets, and RW = risk weight, which is set equal to $40 \%$ for residential mortgages and $75 \%$ for other retail credit.

If banks choose the IRB Approach for retail credit exposures, the banks must estimate PD and LGD, as well as EAD. No explicit maturity factor is included in the functions since the correlation assumptions for the various types of retail exposures (shown below) reflect the average maturity of the retail exposures. Moreover, no distinction exists between the Foundation and Advanced IRB approach for retail credit.

On July 10, 2002, the BIS Basel Committee reached agreement on proposals for several internal ratings-based models for retail credit risk measurement. For the three types of retail credit (residential mortgages, revolving credit and other retail loans), these models specify the risk-weighted assets, as well as the amount of capital banks must hold 
for each portfolio comprised of retail credit exposures. The Technical Guidance manual (BIS (2002)) details each model. For all retail exposures, banks provide assessments of the probability of default (PD) as well as loss given default (LGD).

As shown in Figure 1 (for LGD set equal to 45\%), the highest risk weights among all retail credits are assigned to residential mortgages. The July 2002 BIS proposal stipulates that the capital requirement for residential mortgages is to be calculated as follows:

$$
\mathrm{K}=\mathrm{LGD} \times \mathrm{N}[1 / \sqrt{1-R} x G(P D)+(R / \sqrt{1-R} x G(0.999)]
$$

Where $\mathrm{N}=$ the cumulative distribution function for a standard normal random variable, $\mathrm{G}$ = inverse cumulative distribution function for a standard normal random variable, and $\mathrm{R}=$ correlation. For residential mortgages, the correlation is set at 0.15 .

\section{INSERT FIGURE 1 AROUND HERE}

The capital requirements for other retail credits are similar to those shown in equation (2), with a proposed correlation function for other retail credits that differs from the flat 0.15 correlation assumption applied to residential mortgages. Thus, the BIS July 2002 proposals for minimum capital levels required against other retail credits are:

$$
\mathrm{K}=\mathrm{LGD} \times \mathrm{N}[1 / \sqrt{1-R} x G(P D)+(R / \sqrt{1-R} x G(0.999)]
$$

Where $\mathrm{N}=$ the cumulative distribution function for a standard normal random variable, $\mathrm{G}=$ inverse cumulative distribution function for a standard normal random variable, and $\mathrm{R}=$ correlation. The proposed correlation expression is:

$$
\mathrm{R}=0.02 \times\left(1-e^{-35 x P D}\right) /\left(1-e^{-35}\right)+0.17 x\left[1-\left(1-e^{-35 x P D}\right) /\left(1-e^{-35}\right)\right]
$$

The impact of the correlation expression in equation (3) is to decrease the correlation coefficient at higher levels of PD. Table 1 shows that the risk weight for other retail 
credits is slightly above the risk weight for residential mortgages at low levels of PD (below $0.50 \%$ ), but decreases (relative to the risk weight for residential mortgages) at higher levels of PD, as a result of the assumed inverse relationship between correlation and PD in equation (3) ${ }^{\mathrm{B}}$ Thus, as PD exceeds $0.50 \%$, the correlation on other retail credits calculated using equation (3) falls below 0.15 , thereby lowering the risk weight and the bank's capital requirement for other retail credit as compared to residential mortgages. 4

\section{INSERT TABLE 1 AROUND HERE}

The third model is proposed for the measurement of bank capital requirements for revolving credit. As shown in Figure 1, revolving credit has the lowest capital requirement of all three retail credits under the proposed July 2002 IRB. The lower capital requirements for revolving credit reflects a belief that although retail products have higher rates of estimated default and higher loss given default (LGD), the correlation among retail products is lower than among wholesale products. (See RMA (2000).) This assumption is reflected in the proposed regulations in two ways. First, the correlation expression for revolving credits is lower (at each level of PD) than the correlation for other retail credits (and lower than the correlation for residential mortgages at most levels of PD). Second, the capital requirement is lowered for revolving exposures to allow $90 \%$ of expected losses to be covered by future income.

\footnotetext{
${ }^{3}$ The assumption of an inverse relationship between PD and correlation is quite controversial. Most academic studies find a direct relationship such that higher quality, low PD firms tend to have less systematic risk and therefore lower correlations, whereas lower quality, high PD firms are more subject to market shocks and therefore have higher correlations. See Allen and Saunders (2002) for a discussion. ${ }^{4}$ That is, the risk weight and capital requirements for both residential mortgages and other retail credits increase as PD increases (holding LGD constant), but the risk weight for residential mortgages increases by more than the risk weight for other retail credits at higher PD levels.
} 
Thus, the July 2002 IRB proposals for minimum capital requirements for revolving credit are:

$$
\mathrm{K}=\mathrm{LGD} \times \mathrm{N}[1 / \sqrt{1-R} x G(P D)+(R / \sqrt{1-R} x G(0.999)]-(0.90 \mathrm{PD} \times \mathrm{LGD})
$$

For revolving exposures, the correlation is:

$$
\mathrm{R}=0.02 \times\left(1-e^{-50 x P D}\right) /\left(1-e^{-50}\right)+0.15 x\left[1-\left(1-e^{-50 x P D}\right) /\left(1-e^{-50}\right)\right]
$$

The last term in equation (4) reduces the capital requirement on revolving credits by $90 \%$ of expected losses (PD x LGD). Comparing equation (5) to (3) shows the lower correlation (at each level of PD) for revolving credits as compared to other retail credits.

Carey (2001) sees several challenges to small business lenders posed by the Basel proposals. Banks using credit scoring must convert their scores into variables stipulated in the Basel formula. The results of most credit scoring models are binary: the borrower is either a "good" risk or a "bad" risk. Banks must find a method to convert these scores into probabilities of default (i.e. PD's). The conversion could be problematic in that the score could have different meanings in different economic settings. That is, the same score could represent vastly different probabilities of default depending on the state of the economy. Data pose another challenge. The Accord requires banks to record how well their models prepared them for losses. That is, the banks must keep a record of projected losses and compare the projections with actual losses over time. This requirement forces banks to implement new tracking systems since, according to RMA (2000), many banks have information on retail loans for the most recent 48 months at most. Moreover, even less sophisticated banks will be required to perform complicated, data-intensive backtesting of their models. 
Another problem could be the different assessments banks assign to the same type of product. Since individual loan risk assessment is not economically feasible, banks group their retail loans into portfolios along product lines. RMA (2000) gathered information from 11 U.S. and Canadian banks on how they measure credit risk for retail products and identified eight distinct retail product lines: first mortgages, credit cards, leasing, student loans, other secured retail loans, other unsecured retail loans, home equity loans and home equity lines of credit. If a bank assesses a higher probability of default or loss given default for a particular product line, then that bank must hold more capital than a bank that assigns a lower probability. The RMA study examined how banks assign two important characteristics of risk: expected default frequency and loss given default along retail product lines. Overall, loss given default tends to be higher for retail products (except first mortgages) than for wholesale loans, but correlations among retail loans tends to be lower. Banks assigned similar risk characteristics for six of the products - first mortgages, credit cards, leasing, student loans, other secured, and other unsecured loans. Banks differed mainly on their assessments of two other products, namely home equity loans and home equity lines of credit. In assigning these risk characteristics, banks often make use of the traditional models of credit risk measurement that will be surveyed in the next section.

\section{Traditional Approaches to Credit Risk Measurement}

Traditional methods focus on estimating the probability of default (PD) and typically specify "default" to include bankruptcy filing, default, or liquidation. We consider three broad categories of traditional models used to estimate PD: (1) expert 
systems, including artificial neural networks; (2) rating systems; and (3) credit scoring models.

\subsection{Expert Systems}

Historically, bankers have relied on loan officer expert systems such as the 5 C's of credit to assess credit quality: character (reputation), capital (leverage), capacity (earnings volatility), collateral, and cycle (macroeconomic) conditions. Evaluation of the 5 C's is performed by human experts, who may be inconsistent and subjective in their assessments. Moreover, traditional expert systems specify no weighting scheme that would consistently order the 5 C's in terms of their relative importance in forecasting PD. Thus, artificial neural networks have been introduced to develop more objective expert systems. A neural network is "trained" using historical repayment experience and default data. Structural matches are found that coincide with defaulting firms and then used to determine a weighting scheme to forecast PD. Each time that the neural network evaluates the credit risk of a new loan opportunity, it updates its weighting scheme so that it continually "learns" from experience. Thus, neural networks are flexible, adaptable systems that can incorporate changing conditions into the decision making process.

Empirical tests of the accuracy of neural networks produce mixed results. Kim and Scott (1991) use a supervised artificial neural network to predict bankruptcy in a sample of 190 Compustat firms. While the system performs well (87\% prediction rate) during the year of bankruptcy, its accuracy declines markedly over time, showing only a $75 \%, 59 \%$, and $47 \%$ prediction accuracy one-year prior, two-years prior, and three-years prior to bankruptcy, respectively. Altman et al. (1994) examine 1,000 Italian industrial firms from 1982-1992 and find that neural networks have about the same level of 
accuracy as do credit scoring models. Podding (1994), using data on 300 French firms collected over three years, claims that neural networks outperform credit scoring models in bankruptcy prediction. However, he finds that not all artificial neural systems are equal, noting that the multi-layer perception (or back propagation) network is best suited for bankruptcy prediction. Yang et al. (1999) uses a sample of oil and gas company debt to show that the back propagation neural network obtained the highest classification accuracy overall, when compared to the probabilistic neural network, and discriminant analysis. However, discriminant analysis outperforms all models of neural networks in minimizing type 2 classification errors, that is, misclassifying a good loan as bad.

During "training" the neural network fits a system of weights to each financial variable included in a database consisting of historical repayment/default experiences. However, the network may be "overfit" to a particular database if excessive training has taken place, thereby resulting in poor out-of-sample estimates. Moreover, neural networks are costly to implement and maintain. Because of the large number of possible connections, the neural network can grow prohibitively large rather quickly. Finally, neural networks suffer from a lack of transparency. Since there is no clear economic interpretation that can be attached to the hidden intermediate steps, the system cannot be checked for plausibility and accuracy. Structural errors will not be detected until PD estimates become noticeably inaccurate.

\subsection{Internal Rating Systems}

The Office of the Comptroller of the Currency (OCC) in the United States has long required banks to use internal ratings systems to rank the credit quality of loans in their portfolios. However, the rating system has been rather crude, with most loans rated 
as Pass/Performing and only a minority of loans differentiated according to the four nonperforming classifications (listed in order of declining credit quality): other assets especially mentioned, substandard, doubtful, and loss. Similarly, the National Association of Insurance Commissioners requires insurance companies to rank their assets using a rating schedule with six classifications corresponding to the following credit ratings: $\mathrm{A}$ and above, $\mathrm{BBB}, \mathrm{BB}, \mathrm{B}$, below $\mathrm{B}$, and default.

Many banks have instituted internal ratings systems in preparation for the BIS New Capital Accords scheduled for implementation in 2006. The architecture of the internal rating system can be one-dimensional, in which an overall rating is assigned to each loan based on the probability of default (PD), or two-dimensional, in which each borrower's PD is assessed separately from the loss severity of the individual loan. Treacy and Carey (2000) estimate that 60 percent of the financial institutions in their survey had one-dimensional rating systems, although they recommend a two-dimensional system. Moreover, the BIS (2000) found that banks were better able to assess their borrowers' PD than their loss given default.

Treacy and Carey (2000) in their survey of the 50 largest US bank holding companies, and the BIS (2000) in their survey of 30 financial institutions across the G-10 countries found considerable diversity in internal ratings models. Although all used similar financial risk factors, there were differences across financial institutions with regard to the relative importance of each of the factors. Treacy and Carey (2000) found that qualitative factors played more of a role in determining the ratings of loans to small and medium-sized firms, with the loan officer chiefly responsible for the ratings, in 
contrast with loans to large firms in which the credit staff primarily set the ratings using quantitative methods such as credit-scoring models. Typically, ratings were set with a one year time horizon, although loan repayment behavior data were often available for 35 years.

\subsection{Credit Scoring Models}

The most commonly used traditional credit risk measurement methodology is the multiple discriminant credit scoring analysis pioneered by Altman (1968). Mester (1997) documents the widespread use of credit scoring models: 97 percent of banks use credit scoring to approve credit card applications, whereas 70 percent of the banks use credit scoring in their small business lending. There are four methodological forms of multivariate credit scoring models: (1) the linear probability model, (2) the logit model, (3) the probit model, and (4) the multiple discriminant analysis model. All of these models identify financial variables that have statistical explanatory power in differentiating defaulting firms from non-defaulting firms. Once the model's parameters are obtained, loan applicants are assigned a Z-score assessing their classification as good or bad. The Z-score itself can be converted into a PD.

Credit scoring models are relatively inexpensive to implement and do not suffer from the subjectivity and inconsistency of expert systems. Table 2 shows the spread of these models throughout the world, as surveyed by Altman and Narayanan (1997). What is striking is not so much the models' differences across countries of diverse sizes and in

\footnotetext{
${ }^{5}$ In order to adopt the Internal-Ratings Based Advanced Approach in the new Basel Capital Accord, banks must adopt a risk rating system that assesses the borrower's credit risk exposure (LGD) separately from that of the transaction.

${ }^{6}$ A short time horizon may be appropriate in a mark to market model, in which downgrades of credit quality are considered, whereas a longer time horizon may be necessary for a default mode that considers only the default event. See Hirtle et al. (2001).
} 
various stages of development, but rather their similarities. Most studies found that financial ratios measuring profitability, leverage, and liquidity had the most statistical power in differentiating defaulted from non-defaulted firms.

\section{INSERT TABLE 2 AROUND HERE}

One of the most widely used credit scoring systems was developed by Fair, Isaac and Co. Inc. (FICO). During the 1960's and 1970's, the firm created credit scoring systems tailored to meet the needs of individual clients, mainly retail stores and banks in the United States. In the 1980's, Fair, Isaac serviced more industries including insurance, as well as more countries in Europe. During the 1990's, the firm developed products to evaluate credit of small businesses including trade credit (CreditFYI.com) in 1998 and loan credit (LoanWise.com) in 1999. Personal credit evaluation became more accessible with the development of myfico.com in 2001. Customers can determine their credit score directly using the internet.

Credit scoring systems vary according to the information they evaluate and how they evaluate it. For example, Fair, Isaac assesses credit reports and credit history to determine a score that ranges between 300 and 850 . The assessment considers all outstanding debt such as mortgage loans and credit card balances as well as the proportion of balances to credit limits on credit cards. Payment history, such as whether and how often an individual was late in making payments as well as the length of the credit history is also included. The evaluation does not include characteristics that could bias a lender such as race, religion, national origin, gender, or marital status. However, the evaluation also ignores salary and occupation so that a person with a good, steady 
income and a history of always paying his/her credit card receivables may not achieve a perfect score.

Some shortcomings of credit scoring models are data limitations and the assumption of linearity. Using analysis of variance, discriminant analysis fits a linear function of explanatory variables to the historical data on default and repayment. Moreover, as shown in Table 2, the explanatory variables are predominately limited to balance sheet data. These data are updated infrequently and are determined by accounting procedures that rely on book, rather than market valuation. Finally, there is often limited economic theory as to why a particular financial ratio would be useful in forecasting default.

Recent modifications of credit scoring have given banks the opportunity to treat small business loans as retail credit. That is, before the application of credit scoring to small business loans, such loans were usually made on a relationship basis. The following section explains the differences and implications of relationship versus transactional lending.

\section{Pricing of Small Business Loans}

Loans to small businesses differ from loans to large businesses. Peterson (1999) suggests three major differences. First, since lenders face fixed costs in lending, lending to small firms is by definition more expensive per dollar lent. Second, the relationship between the owner/manager of a small firm and a small bank is often very close. Finally, small firms are more informationally opaque. Because of these structural features, banks can choose how they treat their retail credits for risk analysis purposes. Some (usually 
small) banks attempt to treat their small business customers the same way that they treat their large commercial borrowers. Balance sheet and income statement data are collected and analyzed. When such data are not available, as is often the case in small businesses, modifications are made. Analysis consisted of bypassing the need for "hard" data by building a relationship with the owner/manager and therefore obtaining the necessary information to assess the credit-worthiness of the client. Such relationship lending differs markedly from the current trend toward transactional lending.

In contrast to relationship small business loans, transactional loans are pooled together and treated as if they are a homogenous portfolio. Thus, rather than ascertaining the risk characteristics of a particular borrower, the bank analyzes the overall PD and LGD of the entire portfolio of transactional retail loans. This approach to small business lending is used most often by large banks, whereas smaller banks typically specialize in relationship lending to small businesses; see Berger and Udell (1995) and Petersen and Rajan (1994).

\subsection{Relationship Lending}

Banks that engage in relationship lending often obtain information about their clients that is proprietary. Banks form a special bond with their clients either by serving them over time or providing many products simultaneously (see Boot (2000)). Peterson (1999) suggests that relationship lending is similar to taking an equity stake in a firm. Berlin and Mester (1998) show how relationship lending can lead to loan rate smoothing over time. Relationship lending is based on "soft" data such as personal connections and reputation. 


\subsubsection{Pricing Relationship Loans}

Most research on the pricing of small business loans looks at the length and breadth of the relationship between the bank and its client. The research then determines how that relationship affects the price of the loan. Studies by Peterson and Rajan (1994) and Berger and Udell (1995) show that relationship banking results in new borrowers subsidizing established borrowers. That is, banks charge clients with whom they have had long-term relationships lower interest rates than new clients.

The competitive structure of the banking industry influences these findings. Rajan and Petersen (1995) theorize that banks in competitive markets need to make a profit from clients as soon as possible since the clients may seek other providers. Inderst and Mueller (2002) extend the Rajan-Peterson results with a model that shows that in the presence of credit risk, the lender must obtain the full surplus from the project or else the lender will be too conservative in its lending policy and not finance projects with positive net present values. Bergstresser (2001) tests the Rajan-Peterson theory and shows that concentrated markets have fewer constrained borrowers, because concentrated markets are able to extract more rents from borrowers, thereby allowing banks in concentrated markets "to take more chances." As the relationship between the client and the bank matures, the bank charges a lower interest rate on the loans it extends to that client. However, the drop in interest rates is more pronounced in competitive markets than in concentrated markets. These results are consistent with the Rajan-Petersen model.

\subsubsection{Drawbacks of Relationship Lending}

Relationships are expensive to establish and maintain. Time and resources must be readily available for the recipients of relationship loans. While small banks have a 
competitive advantage in making relationship loans (see Berger and Udell (1996)), the banks themselves may remain small since they cannot generate enough business to become large. Relationships are particularly expensive for large banks since large banks have sufficient capital to make large loans. Spending time to cultivate small accounts is simply not an efficient use of resources when the same amount of effort can result is a much larger loan.

Moreover, the special relationship between the bank and client may not maximize profits for the bank. Berlin and Mester (1998) show that loan rate smoothing in light of interest rate shocks can be profitable for banks that engage in relationship lending, but such smoothing as a result of credit risk shocks can be detrimental to the profitability of lending institutions.

Relationship lending could also lead to discrimination. Cavalluzzo et al. (2002) examine credit granted to small businesses based on the gender, race, and ethnicity of the owner. Even after controlling for personal and business credit histories, the authors find denial rates for black men are substantially higher than for white men. Also, women tend to receive fewer loans in concentrated markets. However, competition within a local banking area appears to lower discrimination.

Despite the costs, large banks have recently taken an interest in small business lending. This interest stems in part from the pressure of disintermediation that caused large banks to lose business as many of their more lucrative clients go directly to the capital markets. Moreover, the interest could reflect a desire to obtain higher, more consistent profits. Bassett and Brady (2001) report that between 1985 and 2000, the net interest margins of banks was consistently about 1 percent higher for small banks than for 
large banks, suggesting that small banks are able to extract more profit from the loans they make. During the same time period, small banks experienced a gradual increase in return on assets (ROA) from approximately 0.7 percent to 1.1 percent. The ROA for large banks vacillated from a low of $-0.4 \%$ in 1987 to 1.1 percent in 2000 . Large banks therefore have an incentive to capture part of the lucrative retail loan market. If large banks learn to make retail loans efficiently, they might smooth their earnings and perhaps increase their net interest margins and therefore revenues and profits. This interest in retail credit by large banks has spurred new ways of making loans to small businesses, namely transactional lending.

\subsection{Transactional Lending}

In contrast to relationship lending, transactional lending is based on portfolio risk measurement tools, such as credit scoring (described in Section 3.3). Banks review loan applications based on specific, quantifiable criteria. One widely used model is by Fair, Isaac, and another model is by SMEloan. Although credit scoring results may be quite inaccurate for informationally-opaque small business borrowers, banks anticipate a portfolio diversification effect based on the average performance of the entire transactional loan portfolio.

Using its credit scoring model for individual consumers, Fair, Isaac and Co. Inc. developed its Small Business Scoring System (SBSS) in the early 1990s. The impetus for the SBSS came from Robert Morris Associates (RMA), renamed Risk Management Association, a group representing credit risk managers from over 3,000 financial institutions. The practitioners from RMA noticed that repayment of small business loans depended less on the business itself than on the credit history of the founder. That is, an 
individual who repays debts is likely to run a small business that repays its debts. RMA asked Fair, Isaac to develop a model based on their observations. Fair, Isaac studied the data collected by 17 banks on 5,000 small business loans. Fair, Isaac analyzed hundreds of pieces of data collected on each loan and determined that fewer than a dozen aspects of the borrower were important. These aspects included total assets of the firm as well as the time in business. Fair, Isaac also verified the observations of the practitioners, namely the characteristics of the owner - e.g. age, number of dependents, and time at address - were more important than the business itself. In 2002, over 350 U.S. lenders used the system in the analysis of over one million credit decisions.

SMEloan focuses not on the owner of a small business, but rather on fundamentals of the individual business. Established in 1999 in Hong Kong, SMEloan is based on the premise that financial statements of a small business do not reveal the true state of the firm's potential and that collateral is usually not worth much in the case of default. SMEloan patterns its small business loan model on a credit card model that looks at a few, simple pieces of data. In the case of small businesses, SMEloan collects data on sales, cash flow, and accounts receivable. As with credit cards, the lender monitors loans in the context of a portfolio and focuses only on small businesses that experience problems.

Banks that use credit scoring models appear to be more productive at lower costs. Longenecker et al. (1997) report the results of Hibernia Corporation, which implemented credit scoring in 1993. Loan officers went from processing 100 applications per month in 1993 to 1,100 in 1995 . The business loan portfolio increased from $\$ 100$ million to $\$ 600$ 
million during the same time period. Moreover, the bank appeared to make fewer bad loans.

Feldman (1997) details the advantages of credit scoring. No face to face contact is necessary so the bank can be located anywhere and still make the loan. Documentation is minimal since only the credit history of the owner/borrower is reviewed. Review is therefore much faster and probably results in lower costs. Loan losses could also be reduced as the portfolio diversification effect results in fewer bad loans on average. Lending volume can also increase substantially.

One implication of credit scoring is that banks can lend to clients located farther and farther away. Petersen and Rajan (2001) show that this long-distance lending stems from greater bank productivity. Banks not only have more information, but they are able to use the information they have more productively. Petersen and Rajan (2001) find that banks are providing small business loans to clients who are located in ever more geographically dispersed regions. This has the advantage of shielding the bank's portfolio from the effects of imperfect geographic diversification. Petersen and Rajan (2001) also show that banks are able to provide such geographically diversified loans, because hard data concerning the clients are now available. Moreover, bank productivity has increased.

Credit scoring also affords benefits to borrowers. Not only is credit more available, but competition is also stronger since more banks can cover wider areas of business. One implication is that borrowers are no longer at the mercy of their local banks. Singletary (1995) reports that, “Now, small-business owners don't have to grovel at the loan officer's desk." 
One reason transaction loans are possible in the United States is that credit information is readily available. Staten (2001) points out that the United States is unusual is promoting the dissemination of credit reports. Such information allows lenders to assess the credit-worthiness of borrowers and therefore provides more credit in the economy. Not only is credit information available, but it is more complete in that credit reports show both positive and negative history. Some countries report only negative credit information on clients. Banks in "negative-only" reporting countries such as in Australia extend fewer loans. In a simulation, Staten (2001) reports that at a targeted default rate of $4 \%$, the negative-only model extended loans to $11 \%$ fewer applicants than the full model. For every 100,000 applicants, the negative-only model extended 11,000 fewer loans. Since credit has a multiplier effect, the restriction of credit can lower the growth of an economy.

\subsubsection{Pricing Transactional Loans}

Pricing relationship loans is vastly different from pricing transactional loans.

Transactional lending to small businesses is based on hard data, such as the credit history of the borrowers (e.g. Fair, Isaac model) or accounts receivable (e.g. SMEloan). Thus, lending rates can reflect credit scores for transactional loans. For example, www.myFICO.com (2003) details the different national average home lending rates for different levels of FICO scores. People with higher credit scores pay lower interest rates. In another example, Feldman (1997) reports that Wells Fargo charges small businesses a range of interest rates from prime plus one percent to prime plus eight percent based on the business' credit score. Such gradations may not be possible if based on human 
judgment (i.e. expert models) because of concerns about objectivity and consistency across borrowers.

There appears to be a systematic difference in the way banks treat relationship loans as compared to transactional loans. Cole et al. (1999) document that large banks use credit scoring for small business loans while small banks tend to make loans based on relationships. Using probit analysis, the authors analyze the influence of loan, relationship, and firm financial characteristics on the probability of a bank extending a loan. They find that large banks tend to "go by the numbers" and characteristics such as high debt-to-assets and low cash-to-assets reduce the probability of a large bank extending a loan. Relationship characteristics are more important for the decisions of small banks with the deposit relationship increasing the likelihood of the small bank extending a loan and the loans outstanding relationship decreasing the likelihood. Interestingly, a borrower with past delinquencies has a lower likelihood of obtaining a loan from a small bank than a larger one. As Peterson (1999) points out, the result is surprising since relationships should allow for a more troubled past. Another interesting result is that African American borrowers tend to have more difficulty obtaining loans from large banks than small banks. Cole et al. (1999) posit that minority status could be a proxy for the owner's (lack of a) credit history.

\subsubsection{Drawbacks of Transactional Lending}

Despite the advantages of credit scoring for small business loans, Mester (1997) reports that only $8 \%$ of banks with up to $\$ 5$ billion in assets used scoring for small business loans. Perhaps small banks are reluctant to switch to the use of quantitative models, fearing their customers will miss the personal service of relationship lending. 
However, Burger et al. (1997) point out that customers left the warmth of "mom and pop" shops in droves when they realized the savings and convenience they could have by shopping at Wal-Mart.

Small banks apparently believe that they have advantages in making small business loans. Indeed, Berger et al. (2001a) show that large and foreign-owned banks tend to lend to large, urban clients suggesting small banks have a competitive advantage in lending to small firms. However, the study is based on data are from Argentina. In other countries such as the United States, the availability of credit scoring models and the information needed to run the models may suggest that we cannot generalize from the results of this study.

The special relationship between banks and their clients is lessened or lost when lending becomes a transactional exercise. Banks are perceived as having superior information concerning the clients to whom they lend. Dahiya et al. (2001) show that the market reacts negatively when a bank sells a loan in its portfolio. The perception is wellfounded: firms whose loans are sold have a higher probability of bankruptcy than firms that do not. This special relationship is lost as soon as the loans are treated as transactional retail exposures.

To address some of these concerns, the Risk Management Association advertises: "Is personal service key to your success? Is relationship banking more important to you than transaction-based business?... [If so], have we got a tool for you! The RMA/Fair, Isaac Small Business Scoring Service (SBSS) will dramatically increase the power and effectiveness of your bank's customer-focus, relationship-oriented strategy. When you 
use SBSS to score your small business loans, you enhance your ability to manage credit risks and maximize the potential of the small business market."

Transactional lending's apparent lack of personal touch could also be overcome. Pine et al. (1995) point out the use of hard data could lead to "mass customization." Such customization, however, relies on managing customer needs as opposed to managing products. Products could be priced individually just as Dell computers are individually created to suit individual needs, but are still able to turn the company a profit. Furthermore, relationship databases could be established. This would combine the informational benefits of relationship lending, with the cost efficiencies of transactional lending.

\subsubsection{Consolidation and Transactional Lending}

The trend toward consolidation within the financial services industry could lead to fewer, more expensive loans to small businesses. Since small banks tend to put more of their assets toward small loans and have a comparative advantage in relationship lending, large banks would reduce overall credit availability for small businesses. Loans to small businesses would then fall in areas where consolidation is higher.However, empirical analysis does not support this hypothesis. Although large banks tend to treat small business loans as retail credit, Black and Strahan (2002) show that credit to small businesses actually increases in areas where markets where consolidation is more prevalent. The authors suggest that the result stems from the observation that large banks are better at risk diversification than small banks. Treating small business loans as transactional retail credit, therefore, may actually help small business entrepreneurs. Moreover, competitive markets seem to supply entrepreneurs with more credit than less 
competitive markets. Berger et al. (2001b) find interest rates to small businesses lower in markets dominated by large banks. Berger et al. (1998) find that other financial institutions pick up any small business loans that may be lost during the consolidation process. Scott and Dunkelberg (1999) also find little impact of bank mergers on credit availability or cost.

Kahn et al. (2001) show that bank consolidation affects different types of retail loans differently. Interest rates on unsecured personal loans that are usually heterogeneous tend to increase after mergers, whereas rates on auto loans tend to fall. The authors explain their findings with the observation that strong competition exists for car loans. Banks can take advantage of scale economies in providing car loans. They further substantiate their suggestion by noting that when one bank lowers its rates on car loans, other banks follow suit.

As the retail loan market moves toward more analytical, data-based transactional lending, there is increased opportunity to adapt modern models of credit risk measurement for the retail market. In the next section, we briefly survey the two major strands of the literature - structural models and reduced form models of credit risk measurement.

\section{Structural Models of Credit Risk Measurement}

Modern methods of credit risk measurement can be traced to two alternative branches in the asset pricing literature of academic finance: an options-theoretic structural approach pioneered by Merton (1974) and a reduced form approach, which uses intensity-based models to estimate stochastic hazard rates, following a literature 
pioneered by Jarrow and Turnbull (1995), Jarrow et al. (1997), Duffie and Singleton (1998), and Duffie and Singleton (1999). These two schools of thought offer differing methodologies to accomplish the central task of all credit risk measurement models estimation of default probabilities. The structural approach models the economic process of default, whereas reduced form models decompose risky debt prices in order to estimate the random intensity process underlying default. The two approaches can be reconciled if asset values follow a random intensity-based process, with shocks that may not be fully observed because of imperfect accounting disclosures. See Duffie and Lando (2001), Zhou (1997), and Zhou (2001). No formal model for retail credit has yet used the reduced form approach, although one model, Credit Risk Plus, could be used for retail credit.

We first discuss the options-theoretic structural approach, which is used by KMV's Portfolio Manager and Moody's RiskCalc to determine default probabilities. The KMV model includes an adaptation for retail credit. We then discuss the possibilities of using the reduced form approach, which forms the basis for Credit Risk Plus.

Merton (1974) models equity in a levered firm as a call option on the firm's assets with a strike price equal to the debt repayment amount (denoted $B$ in Figure 2). If at expiration (coinciding to the maturity of the firm's short-term liabilities (usually one year), assumed to be comprised of pure discount debt instruments) the market value of the firm's assets (denoted $A$ in Figure 2) exceeds the value of its debt, then the firm's shareholders will exercise the option to "repurchase" the company's assets by repaying the debt. However, if the market value of the firm's assets falls below the value of its debt $(A<B)$, then the option will expire unexercised and the firm's shareholders will 
default. $\square$ The PD until expiration is set equal to the maturity date of the firm's pure discount debt, typically assumed to be one year, though Delianedis and Geske (1998) consider a more complex structure of liabilities. Thus, the PD until expiration is equal to the likelihood that the option will expire out of the money. To determine the PD, the call option can be valued using an iterative method to estimate the unobserved variables that determine the value of the equity call option; in particular, $A$ (the market value of assets) and $\sigma_{A}$ (the volatility of assets). These values for $A$ and $\sigma_{A}$ are then combined with the amount of debt liabilities $B$ that have to be repaid at a given credit horizon in order to calculate the firm's Distance to Default (defined to be $\frac{A-B}{\sigma_{A}}$ or the number of standard deviations between current asset values and the debt repayment amount). The higher the Distance to Default (denoted DD), the lower the PD. To convert the DD into a PD estimate, Merton (1974) assumes that asset values are log normally distributed. Since this distributional assumption is often violated in practice, proprietary structural models use alternative approaches to map the DD into a PD estimate. For example, KMV's Portfolio Manager and Moody's RiskCalc estimates an empirical PD using historical default experience.

\section{INSERT FIGURE 2 AROUND HERE}

\footnotetext{
${ }^{7}$ Assuming that shareholders are protected by limited liability, there are no costs of default, and that absolute priority rules are strictly observed, then the shareholders' payoff in the default region is zero. ${ }^{8}$ Using put-call parity, Merton (1974) values risky debt as a put option on the firm's assets giving the shareholders the right, not the obligation, to sell the firm's assets to the bondholders at the value of the debt outstanding. The default region then corresponds to the region in which the shareholders exercise the put option. The model uses equity volatility to estimate asset volatility since both the market value of firm assets and asset volatility are unobservable. See Ronn and Verma (1986).

${ }^{9}$ The Moody's approach uses a neural network to analyze historical experience and current financial data On February 11, 2002, Moody's announced that it was acquiring KMV for more than \$200 million in cash.
} 


\subsection{KMV's Portfolio Manager}

Three inputs are needed for each loan to calculate the credit risk of a portfolio using KMV's Portfolio Manager: expected return, risk (variance), and correlation.

The distance to default (DD) for individual credits is converted into a probability of default (PD) by determining the likelihood that the firm's assets will traverse the debt boundary point during the credit horizon period. KMV uses a historical database of default rates to determine an empirical estimate of the PD, denoted Expected Default Frequency (EDF). For example, historical evidence shows that firms with DD equal to 4 have an average historical default rate of $1 \%$. Thus, KMV assigns an EDF of $1 \%$ to firms with DD equal to 4. If $\mathrm{DD}>4$ (DD<4), then the KMV EDF is less (more) than $1 \%$. The complete mapping of KMV EDF scores to DD is proprietary. EDFs are calibrated on a scale of $0 \%$ to $20 \%$.

Retail clients do not have a series of equity prices that can be used to estimate asset values or asset volatility. Therefore, KMV modifies its Portfolio Manager model to obtain a loan's EDF and uses estimated values when needed. Specifically, KMV calculates the excess return on a loan $\left(\mathrm{R}_{\mathrm{it}}\right)$ as follows:

$$
\begin{aligned}
& \mathrm{R}_{\mathrm{it}}=\left[\operatorname{Spread}_{\mathrm{i}}+\text { Fees }_{\mathrm{i}}\right]-\left[\text { Expected loss }_{\mathrm{i}}\right]-\mathrm{r}_{\mathrm{f}} \\
& \text { Or } \\
& \mathrm{R}_{\mathrm{it}}=\left[\operatorname{Spread}_{\mathrm{i}}+\text { Fees }_{\mathrm{i}}\right]-\left[\mathrm{EDF}_{\mathrm{i}} \mathrm{X} \mathrm{LGD}_{\mathrm{i}}\right]-\mathrm{r}_{\mathrm{f}}
\end{aligned}
$$

The model uses estimated and proprietary values for the expected default frequency and loss given default since retail credit is not publicly traded. Correlations range from 0.002 to 0.15 .

The risk, or unexpected loss, is calculated as follows: 


$$
\sigma_{\mathrm{i}}=\left[\operatorname{EDF}_{\mathrm{i}}\left(1-\mathrm{EDF}_{\mathrm{i}}\right)\right]^{1 / 2} \times \operatorname{LGD}_{\mathrm{i}}
$$

We report the findings of a study that examines the implementation of credit risk models in banks. The International Swaps and Derivatives Association (ISDA) and the Institute of International Finance (IIF) tested credit risk measurement models in 25 commercial banks from 10 countries. (See IIF/ISDA (2000).) The KMV model is compared to internal models for standardized portfolios (without option elements) created to replicate retail credits.

The results for retail credit showed a range of credit risk estimates. Moreover, proprietary internal models were used most often by the banks participating in the survey for the retail markets portfolio as compared to any other portfolio. These internal models typically focused on default only. Two test portfolios were constructed. The small portfolio was created to emulate a credit card portfolio. Credit facilities ranged from $\$ 0$ to $\$ 5,000$ with an average of just over $\$ 807$. The small portfolio included almost 350,000 distinct borrowers. The large portfolio included facilities ranging in value from $\$ 0$ to $\$ 30,000$ with an average of just over $\$ 12,000$ and almost 170,000 distinct borrowers. The analysts made several assumptions concerning the base case. They assumed expected losses were $1.1(0.6)$ percent for the small (large) portfolio and unexpected losses were $0.4(0.3)$ percent for the respective portfolios. They assumed loss given default was 90 percent with no volatility. For the KMV model, they assumed correlations of 4 percent. Since some models include country information in the analysis, one country, Canada, was chosen for the base case. These assumptions were altered in sensitivity analysis. 


\section{INSERT TABLE 3 AROUND HERE}

As shown in Table 3, there were significant differences in the risk measures estimated by the different models for the retail credit portfolio. At confidence level of 99.97 percent, KMV generated average value at risk (VAR) estimates of 3.6 (2.3) percent for the small (large) portfolio while the corresponding estimates for the internal models were 3.2 (2.7) percent. The KMV results imply that a bank manager can be almost certain (that is, 99.97 percent certain) that the bank will not lose more than $3.6(2.3)$ percent of its small (large) retail portfolio.

Sensitivity analysis included varying correlations, credit quality (expected and unexpected losses), and loss given default. As expected, increases (decreases) in correlation led to considerable higher (lower) values at risk. However, allowing the banks to assume the exposures were in their home countries did not alter VARs much, though one bank reported a slight increase when the exposures were assumed to be located in its home country. Decreases in credit quality increased VARs substantially: Doubling expected and unexpected loss percentages nearly doubled VARs. Finally, reducing LGD from 90 percent to 25 percent reduced VARs to approximately one third of their original values.

\subsection{Moody's RiskCalc}

Moody's RiskCalc seeks to determine which private firms will default on their loans. (For an overview of RiskCalc, see Falkenstein et al. (2000).) Using credit scoring, the analysis looks at a handful of financial ratios to determine which firms are likely to default. Although designed for middle market firms, the model could be used for any firm that is too large to be considered an extension of its owner. That is, the analysis is 
performed on the firm's financial information and not that of the owner. Lenders can currently use RiskCalc to analyze the creditworthiness of firms with $\$ 100,000$ or more in assets.

Patterned after its model for public firms, Moody's determines which financial ratios are most important in determining default of private companies by analyzing previous defaults. The firm creates a proprietary Credit Research Database (CRD) and then weights the ratios according to their historic importance in default. Moody's finds substantial differences between ratios that are important for public firms and those that are important for private firms. The current financial ratios of a firm are multiplied by the weights to determine one- and five-year expected default frequencies. The EDFs can then be mapped into Moody's rating categories. If a particular ratio is missing, RiskCalc uses the mean value of all observations. The more missing data, the less useful the model.

Moody's has compiled separate Credit Research Databases for individual countries around the world. Databases exist for North American countries (the United States, Canada, and Mexico), European countries (the United Kingdom, Germany, Spain, France, Belgium, the Netherlands, Portugal, Italy, and Austria) as well as Japan, Australia, and Singapore. Since the database for each country is different, each country has a separate model. For example, the U.S. CRD consists of almost 34,000 companies and almost 1,400 defaults. The three most important risk factors in the U.S. model are profitability, which has a weight of 23 percent, capital structure with a weight of 21 percent and liquidity/cash flow with a weight of 19 percent. The Singaporean CRD (see Kocagil et al. (2002)) consists of almost 4,500 Singaporean borrowers with about 650 
defaults. Although risk factors are similar to the U.S. model, they are not the same. The weight on profitability is 26 percent, on capital structure is 24 percent, and size is the third most important factor, contributing 14 percent to the model.

Possibilities for applying RiskCalc to retail portfolios exist. Databases would have to be created that examine important ratios specifically for the retail market. Creating databases specific to retail borrowers is particularly important in light of the fact that Moody's finds substantial differences between its models for public and private firms. Extending that result suggests substantial differences could exist between middle and retail markets. Applying the current models for the middle market could lead to incorrect assessment of credit risk in the retail market. The creation of such a database for the retail market, however, could be difficult. Retail borrowers by definition often do not have reliable financial statements.

\subsection{Credit Risk Plus}

Credit Risk Plus, a proprietary model developed by Credit Suisse Financial Products (CSFP), views spread risk as part of market risk rather than credit risk. As a result, in any period, only two states of the world are considered - default and non-default - and the focus is on measuring expected and unexpected losses. Thus, Credit Risk Plus is a default mode (DM) model. Furthermore, Credit Risk Plus models default as a continuous variable with a probability distribution. Thus, Credit Risk Plus is based on the theoretical underpinnings of intensity-based models. An analogy from property fire insurance is relevant. When a whole portfolio of homes is insured, there is a small probability that each house will burn down, and (in general) the probability that each house will burn down can be viewed as an independent event. That is, there is a constant probability that 
any given house will burn down (or equivalently, a loan will default) within a predetermined time period. Credit Risk Plus has the flexibility to calculate default probabilities over a constant time horizon (say, one year) or over a hold-to-maturity horizon. Similarly, many types of loans, such as mortgages and small business loans, can be thought of in the same way, with respect to their default risk. Thus, under Credit Risk Plus, each individual loan is regarded as having a small probability of default, and each loan's probability of default is independent of the default on other loans. This assumption makes the distribution of the default probabilities of a loan portfolio resemble a Poisson distribution.

Moreover, the simplest model of Credit Risk Plus assumes probability of default to be constant over time. A more sophisticated version ties loan default probabilities to the systematically varying mean default rate of the "economy" or "sector" of interest. The continuous time extension of Credit Risk Plus is the intensity-based model of Duffie and Singleton (1998), which stipulates that over a given small time internal, the probability of default is independent across loans and proportional to a fixed default intensity function.

Default rate uncertainty is only one type of uncertainty modeled in Credit Risk Plus. A second type of uncertainty surrounds the size or severity of the losses themselves. Borrowing again from the fire insurance analogy, when a house "catches fire," the degree of loss severity can vary from the loss of a roof to the complete destruction of the house. In Credit Risk Plus, the fact that severity rates are uncertain is acknowledged, but because of the difficulty of measuring severity on an individual loan-by-loan basis, loss severities or loan exposures are rounded and banded (for example, into discrete $\$ 20,000$ severity or 
loss bands). The smaller the bands are, the less the degree of inaccuracy that is built into the model as a result of banding.

The two degrees of uncertainty - the frequency of defaults and the severity of losses produce a distribution of losses for each exposure band. Summing (or accumulating) these losses across exposure bands produces a distribution of losses for the portfolio of loans. The great advantage of the Credit Risk Plus model is its parsimonious data requirements. The key data inputs are mean loss rates and loss severities, for various bands in the loan portfolio, both of which are potentially amenable to collection, either internally or externally.

The assumption of a default rate with a Poisson distribution implies that the mean default rate of a portfolio of loans should equal its variance. However, this assumption does not hold in general, especially for lower quality credits. For B-rated bonds, Carty and Lieberman (1996) found the mean default rate was 7.62 percent and the square root of the mean was 2.76 percent, but the observed standard deviation was 5.1 percent, or almost twice as large as the square root of the mean. Thus, the Poisson distribution appears to underestimate the actual probability of default.

What extra degree of uncertainty might explain the higher variance (fatter tails) in observed loss distributions? The additional uncertainty modeled by Credit Risk Plus is that the mean default rate itself can vary over time (or over the business cycle). For example, in economic expansions, the mean default rate will be low; in economic contractions, it may rise significantly. The most speculative risk classifications' default probabilities are most sensitive to these shifts in macroeconomic conditions. (See Crouhy et al. (2000).) In the extended Credit Risk Plus model, there are three types of 
uncertainty: (1) the uncertainty of the default rate around any given mean default rate, (2) the uncertainty about the severity of loss, and (3) the uncertainty about the mean default rate itself. Credit Risk Plus derives a closed form solution for the loss distribution by assuming that these types of uncertainty are all independent. However, the assumption of independence may be violated if the volatility in mean default rates reflects the correlation of default events through interrelated macroeconomic factors.

Appropriately modeled, a loss distribution can be generated along with expected losses and unexpected losses that exhibit observable fatter tails. The latter can then be used to calculate unexpected losses due to credit risk exposure.

\section{Summary and Conclusion}

The trend in retail credit decision making is strongly toward increased reliance on statistical, data-based models of credit risk measurement. Retail lending has gradually shifted from relationship lending to transactional (portfolio-based) lending. The earliest shift was seen in the area of credit card loans, then mortgage lending became more transactional, and now there is an increased trend toward transactional loans to small businesses. The fact that this transition has come in stages has led to the gradual understanding that transactional lending is not necessarily detrimental to the lending relationship between a bank and a client. Moreover, transactional lending could create a more equitable and liquid financial system. For example, transactional lending does not allow for the subsidization of established borrowers by new borrowers. One problem with transactional lending is that if all banks use the same model, certain borrowers may be rationed out of the market with a higher probability than with relationship lending. 
Moreover, model risk may cause increased correlations in bank returns, engendering cyclical fluctuations in the financial condition of the banking sector, with potentially macroeconomic consequences.

Models such as KMV's Portfolio Manager and CSFB's Credit Risk Plus potentially provide alternative modeling choices. Such models focus on the equity price of the borrowing firm. The problem with such models is that retail borrowers often do not have publicly traded stock and therefore equity prices may not be available or may be unreliable because of liquidity problems. Furthermore, Credit Risk Plus focuses on the middle market and must develop databases that directly assess retail borrowers before the model can be used in retail lending. Models for retail credit exist. Lenders must determine what kind of model they would like and whether to develop it in-house or to buy a credit scoring system. 
Table 1

Illustrative IRB Risk Weights

\begin{tabular}{|c|c|c|c|c|c|c|}
\hline \multirow{2}{*}{$\begin{array}{l}\text { Asset Class: } \\
\text { LGD: } \\
\text { Maturity:2.5 years } \\
\text { PD: }\end{array}$} & \multicolumn{2}{|c|}{ Residential Mortgage } & \multicolumn{2}{|c|}{ Other Retail } & $\begin{array}{c}\text { Qualifying } \\
45 \%\end{array}$ & \multirow{2}{*}{$\begin{array}{r}\text { Revolving } \\
85 \%\end{array}$} \\
\hline & $45 \%$ & $25 \%$ & $45 \%$ & $85 \%$ & $45 \%$ & \\
\hline $0.03 \%$ & $4.31 \%$ & $2.40 \%$ & $4.97 \%$ & $9.38 \%$ & $4.10 \%$ & $7.74 \%$ \\
\hline $0.05 \%$ & $6.51 \%$ & $3.62 \%$ & $7.42 \%$ & $14.02 \%$ & $6.10 \%$ & $11.52 \%$ \\
\hline $0.10 \%$ & $11.25 \%$ & $6.25 \%$ & $12.54 \%$ & $23.68 \%$ & $10.21 \%$ & $19.29 \%$ \\
\hline $0.25 \%$ & $22.70 \%$ & $12.61 \%$ & $23.91 \%$ & $45.16 \%$ & $19.02 \%$ & $35.93 \%$ \\
\hline $0.40 \%$ & $32.19 \%$ & $17.89 \%$ & $32.28 \%$ & $60.98 \%$ & $25.13 \%$ & $47.46 \%$ \\
\hline $0.50 \%$ & $37.89 \%$ & $21.05 \%$ & $36.86 \%$ & $69.63 \%$ & $28.30 \%$ & $53.45 \%$ \\
\hline $0.75 \%$ & $50.68 \%$ & $28.16 \%$ & $46.01 \%$ & $86.90 \%$ & $34.18 \%$ & $64.56 \%$ \\
\hline $1.00 \%$ & $62.03 \%$ & $34.46 \%$ & $52.90 \%$ & $99.93 \%$ & $38.12 \%$ & $72.01 \%$ \\
\hline $1.30 \%$ & $74.31 \%$ & $41.28 \%$ & $59.25 \%$ & $111.91 \%$ & $41.26 \%$ & $77.94 \%$ \\
\hline $1.50 \%$ & $81.88 \%$ & $45.49 \%$ & $62.64 \%$ & $118.33 \%$ & $42.71 \%$ & $80.68 \%$ \\
\hline $2.00 \%$ & $99.19 \%$ & $55.10 \%$ & $69.20 \%$ & $130.71 \%$ & $44.95 \%$ & $84.90 \%$ \\
\hline $2.50 \%$ & $114.70 \%$ & $63.72 \%$ & $73.96 \%$ & $139.71 \%$ & $46.05 \%$ & $86.98 \%$ \\
\hline $3.00 \%$ & $128.86 \%$ & $71.59 \%$ & $77.67 \%$ & $146.71 \%$ & $46.62 \%$ & $88.07 \%$ \\
\hline $4.00 \%$ & $154.13 \%$ & $85.63 \%$ & $83.50 \%$ & $157.72 \%$ & $47.38 \%$ & $89.50 \%$ \\
\hline $5.00 \%$ & $176.35 \%$ & $97.97 \%$ & $88.56 \%$ & $167.29 \%$ & $48.46 \%$ & $91.53 \%$ \\
\hline $6.00 \%$ & $196.27 \%$ & $109.04 \%$ & $93.64 \%$ & $176.87 \%$ & $50.16 \%$ & $94.74 \%$ \\
\hline $10.00 \%$ & $260.66 \%$ & $144.81 \%$ & $117.95 \%$ & $222.79 \%$ & $61.51 \%$ & $116.19 \%$ \\
\hline $15.00 \%$ & $320.10 \%$ & $177.83 \%$ & $154.81 \%$ & $292.41 \%$ & $77.45 \%$ & $146.29 \%$ \\
\hline $20.00 \%$ & $365.62 \%$ & $203.12 \%$ & $192.33 \%$ & $363.29 \%$ & $90.79 \%$ & $171.49 \%$ \\
\hline
\end{tabular}

Source: BIS, Quantitative Impact Study 3 Technical Guidance, October 2002, p. 139. 
Table 2: International Survey of Credit Scoring Models

\begin{tabular}{|c|c|}
\hline STUDIES CITED & \begin{tabular}{|l} 
EXPANATORY VARIABLES \\
\end{tabular} \\
\hline \multicolumn{2}{|l|}{ United States } \\
\hline Altman (1968) & $\begin{array}{l}\text { EBIT/assets; retained earnings/ assets; working capital/assets; } \\
\text { sales/assets; market value (MV) equity/book value of debt. }\end{array}$ \\
\hline \multicolumn{2}{|l|}{ Japan } \\
\hline Кo (1982) & $\begin{array}{l}\text { EBIT/sales; working capital/debt; inventory turnover } 2 \text { years } \\
\text { prior/inventory turnover } 3 \text { years prior; MV equity/debt; standard } \\
\text { error of net income ( } 4 \text { years). }\end{array}$ \\
\hline $\begin{array}{l}\text { Takahashi et al. } \\
\text { (1979) }\end{array}$ & $\begin{array}{l}\text { Net worth/fixed assets; current liabilities/assets; voluntary } \\
\text { reserves plus unappropriated surplus/assets; interest } \\
\text { expense/sales; earned surplus; increase in residual value/sales; } \\
\text { ordinary profit/assets; sales - variable costs. }\end{array}$ \\
\hline \multicolumn{2}{|r|}{ 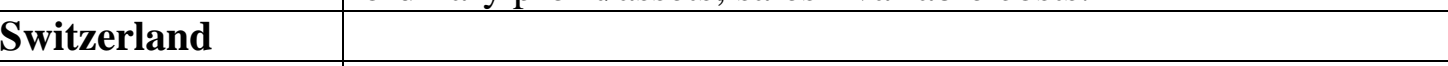 } \\
\hline Weibel (1973) & $\begin{array}{l}\text { Liquidity (near monetary resource asset - current liabilities)/ } \\
\text { operating expenses prior to depreciation; inventory turnover; } \\
\text { debt/assets. }\end{array}$ \\
\hline \multicolumn{2}{|l|}{ Germany } \\
\hline $\begin{array}{l}\text { Baetge, Huss and } \\
\text { Niehaus (1988) }\end{array}$ & $\begin{array}{l}\text { Net worth/(total assets - quick assets - property \& plant); } \\
\text { (operating income + ordinary depreciation + addition to pension } \\
\text { reserves)/assets; (cash income - expenses)/short term liabilities. }\end{array}$ \\
\hline $\begin{array}{l}\text { von Stein and } \\
\text { Ziegler (1984) }\end{array}$ & $\begin{array}{l}\text { Capital borrowed/total capital; short-term borrowed } \\
\text { capital/output; accounts payable for purchases \& deliveries / } \\
\text { material costs; (bill of exchange liabilities + accounts } \\
\text { payable)/output; (current assets - short-term borrowed } \\
\text { capital)/output; equity/(total assets - liquid assets - real estate); } \\
\text { equity/(tangible property - real estate); short-term borrowed } \\
\text { capital/current assets; (working expenditure - depreciation on } \\
\text { tangible property)/(liquid assets + accounts receivable - short- } \\
\text { term borrowed capital); operational result/capital; (operational } \\
\text { result + depreciation)/net turnover; (operational result + } \\
\text { depreciation)/short-term borrowed capital; (operational result + } \\
\text { depreciation)/total capital borrowed. }\end{array}$ \\
\hline \multicolumn{2}{|l|}{ England } \\
\hline $\begin{array}{l}\text { Marais (1979), } \\
\text { Earl \& Marais } \\
(1982)\end{array}$ & $\begin{array}{l}\text { Current assets/gross total assets; 1/gross total assets; cash } \\
\text { flow/current liabilities; (funds generated from operations - net } \\
\text { change in working capital)/debt. }\end{array}$ \\
\hline \multicolumn{2}{|l|}{ Canada } \\
\hline $\begin{array}{l}\text { Altman and } \\
\text { Lavallee (1981) }\end{array}$ & $\begin{array}{l}\text { Current assets/current liabilities; net after-tax profits/debt; rate of } \\
\text { growth of equity - rate of asset growth; debt/assets; sales/assets. }\end{array}$ \\
\hline \multicolumn{2}{|l|}{ The Netherlands } \\
\hline Bilderbeek (1979) & $\begin{array}{l}\text { Retained earnings/assets; accounts payable/sales; added value/ } \\
\text { assets; sales/assets; net profit/equity. }\end{array}$ \\
\hline $\begin{array}{l}\text { van Frederikslust } \\
\text { (1978) }\end{array}$ & $\begin{array}{l}\text { Liquidity ratio (change in short term debt over time); } \\
\text { profitability ratio (rate of return on equity). }\end{array}$ \\
\hline
\end{tabular}




\begin{tabular}{|l|l|}
\hline TABLE 2 & (CONTINUED) \\
\hline STUDIES CITED & EXPLANATORY VARIABLES \\
\hline Spain & $\begin{array}{l}\text { Return on investment; cash flow/current liabilities; quick ratio/ } \\
\text { industry value; before tax earnings/sales; cash flow/sales; } \\
\text { (permanent funds/net fixed assets)/industry value. }\end{array}$ \\
\hline Fernandez (1988) & $\begin{array}{l}\text { Ability to bear cost of debt; liquidity; ability to bear financial } \\
\text { debt; profitability; assets/liabilities; profit accumulation; trade } \\
\text { indebtedness; efficiency. }\end{array}$ \\
\hline Italy & $\begin{array}{l}\text { Altman, Marco, } \\
\text { and Varetto (1994) }\end{array}$ \\
\hline Australia & $\begin{array}{l}\text { EBIT/interest; MV equity/liabilities; EBIT/assets; funded debt/ } \\
\text { shareholder funds; current assets/current liabilities. }\end{array}$ \\
\hline Izan (1984) & $\begin{array}{l}\text { Gross income/current liabilities; debt/assets; net working } \\
\text { capital/assets; gross income/assets; current assets/current } \\
\text { liabilities. }\end{array}$ \\
\hline Greece & $\begin{array}{l}\text { Retained earnings/assets; EBIT/assets; sales/assets; MV equity/ } \\
\text { book value of liabilities. }\end{array}$ \\
\hline $\begin{array}{l}\text { Gloubos and } \\
\text { Grammatikos } \\
\text { (1988) }\end{array}$ & $\begin{array}{l}\text { Cash flow/debt; current ratio; profit after tax/net worth; interest/ } \\
\text { output; sales/assets; stock of finished goods/sales; working } \\
\text { capital management ratio. }\end{array}$ \\
\hline Brazil & $\begin{array}{l}\text { Log(assets); log(sales/assets); retained earnings/assets; MV of } \\
\text { equity/liabilities. }\end{array}$ \\
\hline Ribeiro-Dias,1979, Baidya, \&
\end{tabular}

Notes: Whenever possible, the explanatory variables are listed in order of statistical importance (e.g., the size of the coefficient term) from highest to lowest. Source: Altman and Narayanan (1997). 
Table 3

Summary of IIF/ISDA Results for the Retail Credit Portfolio

\begin{tabular}{|c|c|c|c|c|}
\hline MODEL & Exposure & $\begin{array}{c}\text { Expected Loss } \\
\text { \% }\end{array}$ & $\begin{array}{c}\text { Unexpected } \\
\text { Loss \% }\end{array}$ & $\begin{array}{c}\text { Risk at } \\
\mathbf{9 9 . 9 7 \%}\end{array}$ \\
\hline \multicolumn{5}{|c|}{ Small Portfolio } \\
\hline $\begin{array}{c}\text { KMV Portfolio } \\
\text { Manager }\end{array}$ & 722 & 1.1 & 0.4 & 3.6 \\
\hline Internal Models & 722 & 1.1 & 0.5 & 3.2 \\
\hline \multicolumn{5}{|c|}{ Large Portfolio } \\
\hline $\begin{array}{c}\text { KMV Portfolio } \\
\text { Manager }\end{array}$ & 2,285 & 0.6 & 0.3 & 2.3 \\
\hline Internal Models & 2,245 & 0.6 & 0.3 & 2.7 \\
\hline
\end{tabular}

Source: IIF/ISDA Study, Chapter I, p. 24. 


\section{Figure 1 \\ July 2002 Basel New Capital Accord Proposals Internal Ratings-Based Retail Credit Risk Weights}

Source: BIS (July 2002).

Risk weights are depicted as functions of PD, assuming LGD $=45 \%$

Figure 1: July 2002 BIS Proposals for Retail Credit Capital Requirements

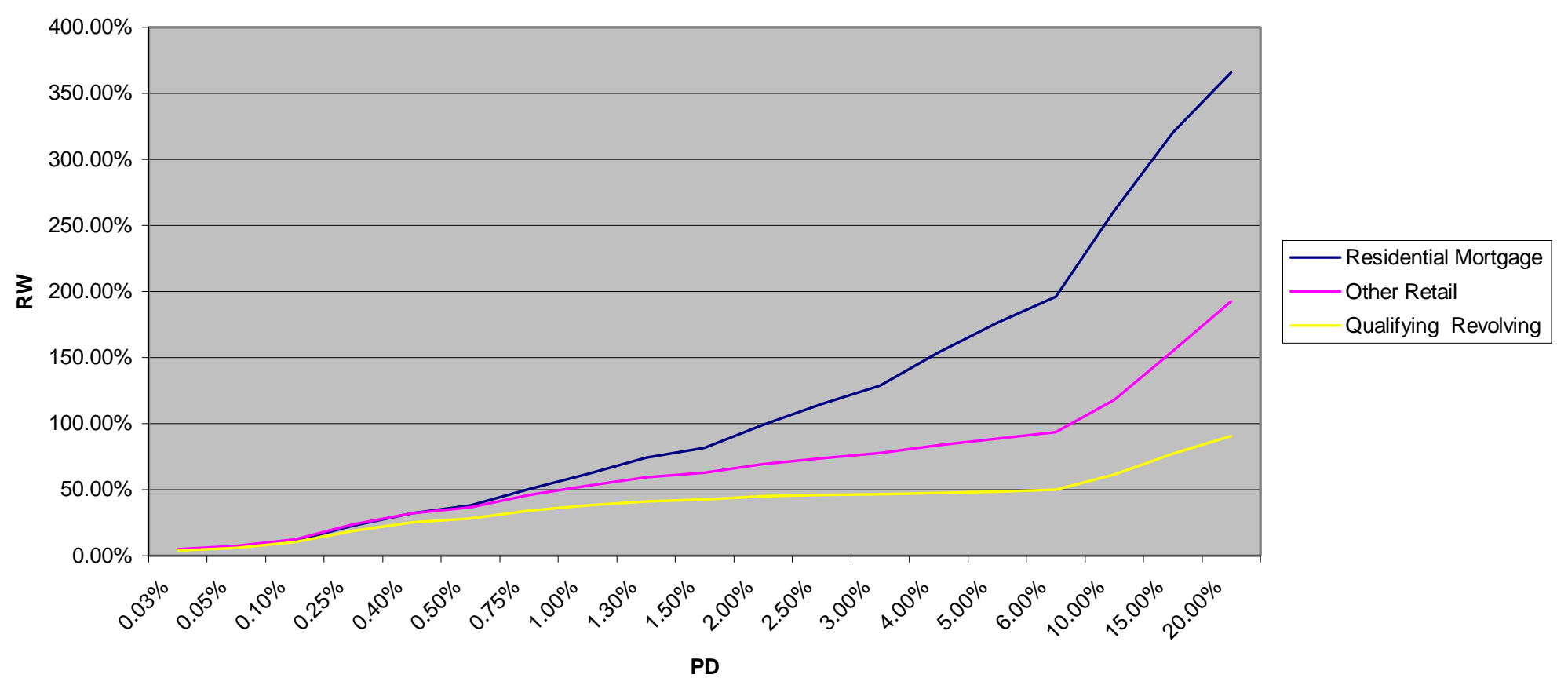




\section{Figure 2}

Figure 4.3 Equity as a call option on a firm.

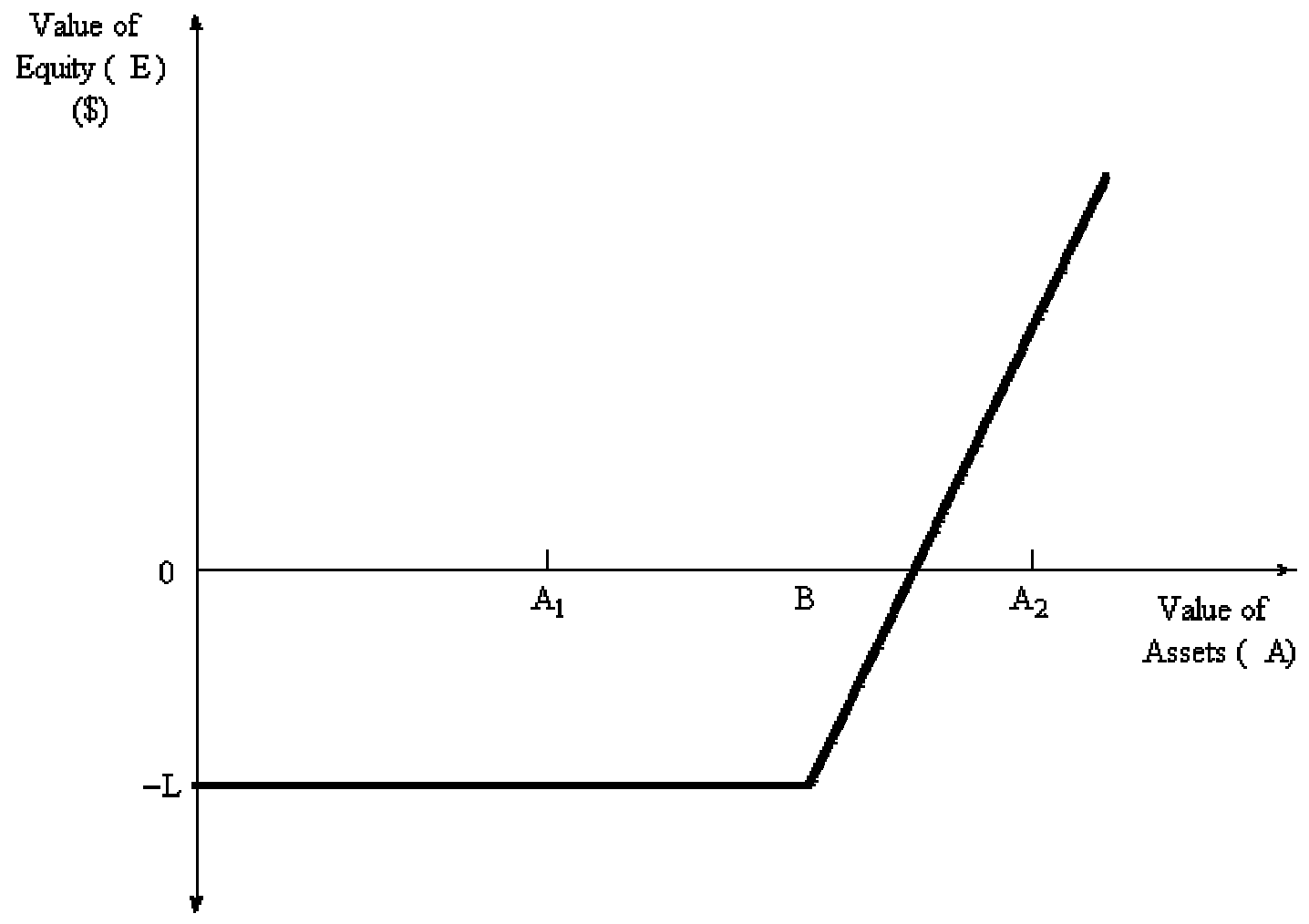




\section{References}

Allen, L. and A. Saunders, "A Survey of Cyclical Effects in Credit Risk Measurement Models," with A. Saunders, Risk Books, forthcoming, BIS working paper 2002.

Altman, E., G. Marco, and F. Varetto (1994) Corporate distress diagnosis: Comparison using linear discriminant analysis and neural networks (the italian experience), Journal of Banking and Finance 18, 505-529.

Altman, E.I. (1968) Financial ratios, discriminant analysis and the prediction of corporate bankruptcy, Journal of Finance 23, 589-609.

Altman, E.I. and P. Narayanan (1997) An international survey of business failure classification models, Financial Markets, Institutions and Instruments 6.

Basset, W.F. and T.F. Brady (2001) The economic performance of small banks, 1985 2000, Federal Reserve Bulletin (November) 719-728.

Berger, A. and G. Udell (1995) Relationship lending and lines of credit in small firm finance, Journal of Business 68, 351-381.

Berger, A.N., L.F. Klapper, and G.F. Udell (2001a) The ability of banks to lend to informationally opaque small businesses, Journal of Banking and Finance 25, (forthcoming).

Berger, A.N., R.J. Rosen, and G.F. Udell (2001b) The effect of banking market size and structure on bank competition: The case of small business lending, Federal Reserve Board working paper, Washington, D.C.

Berger, A.N., A. Saunders, J.K. Scalise, and G. Udell (1998) The effects of bank mergers and acquisitions on small business lending, Journal of Financial Economics 50, 187-229.

Berger, A.N. and G.F. Udell (1996) Universal banking and the future of small business lending, in I. Walter, ed.: Financial System Design: The Case for Universal Banking (Irwin Publishing, Burr Ridge, IL).

Bergstresser, D. (2001) Banking market concentration and consumer credit constraints: Evidence from the survey of consumer finances, Working Paper, MIT. Cambridge, MA.

Berlin, M. and L.J. Mester (1998) On the profitability and cost of relationship lending, Journal of Banking and Finance 22, 873-897.

BIS (2000) Range of practice in banks' internal ratings systems, Basel Committee on Banking Supervision, Document No. 66.

BIS (2001) The internal ratings-based approach, Basel Committee on Banking Supervision, January.

BIS (2002) Quantitative impact study 3 technical guidance, Basel Committee on Banking Supervision, October.

Black, S.E. and P.E. Strahan (2002) Entrepreneurship and bank credit availability, The Journal of Finance 57, 2807-2833.

Boot, A.W.A. (2000) Relationship banking: What do we know?, Journal of Financial Intermediation 9, 7-25.

Burger, A.E., M. Zellmer, and D. Robinson (1997) The digital revolution: Delivering financial services in the future Madison, WI: Filene Research Institute. 
Carey, M. (2001) Small business lending and the new basel capital accord, Making Small Business Lending Profitable. International Finance Corporation, Washington, DC.

Carty, L. and D. Lieberman (1996) Corporate bond defaults and default rates 1938-1999, Moody's Investors Service Global Credit Research, New York, NY.

Cavalluzzo, K.S., L.C. Cavalluzzo, and J.D. Wolken (2002) Competition, small business financing, and discrimination: Evidence from a new survey, Journal of Business 75, 641-679.

Cole, R.A., L.G. Goldberg, and L.J. White (1999) Cookie-cutter versus character: The microstructure of small business lending by large and small banks, Conference on Consumer Transactions and Credit. Federal Reserve Bank of Philadelphia, Philadelphia, PA.

Crouhy, M., D. Galai, and R. Mark (2000) A comparative analysis of current credit risk models, Journal of Banking and Finance 24, 57-117.

Dahiya, S., M. Puri, and A. Saunders (2001) Bank borrowers and loan sales: New evidence on the uniqueness of bank loans, Journal of Business (forthcoming).

Delianedis, G. and R. Geske (1998) Credit risk and risk-neutral default probabilities: Information about rating migrations and defaults, Bank of England Conference on Credit Risk Modeling and Regulatory Implications. London, September 21-22.

Duffie, D. and D. Lando (2001) Term structures of credit spreads with incomplete accounting information, Econometrica 69, 633-664.

Duffie, D. and K.J. Singleton (1998) Simulating correlation defaults, Bank of England Conference on Credit Risk Modeling and Regulatory Implications. London, September 21-22.

Duffie, D. and K.J. Singleton (1999) Modeling term structures of defaultable bonds, Review of Financial Studies 12, 687-720.

Falkenstein, E., A. Boral, and L.V. Carty (2000) Riskcalc for private companies: Moody's default model, Moody's Investors Service Global Credit Research, New York, NY.

Feldman, R. (1997) Small business loans, small bank and a big change in technology called credit scoring, The Region (Federal Reserve Bank of Minneapolis) September.

Gross, D.B. and N.S. Souleles (2002) An empirical analysis of personal bankruptcy and delinquency, Review of Financial Studies (forthcoming).

Hirtle, B.J., M. Levonian, M. Saidenberg, S. Walter, and D. Wright (2001) Using credit risk models for regulatory capital: Issues and options, Economic Policy Review Federal Reserve Bank of New York, March, 19-36.

IIF/ISDA (2000) Modeling credit risk: Joint iif/isda testing program, Institute of International Finance and International Swaps and Derivatives Association, February.

Inderst, R. and H. Mueller (2002) Credit risk analysis and security design, working paper, New York University (New York, NY).

Jarrow, R., D. Lando, and S. Turnbull (1997) A markov model for the term structure of credit spreads, Review of Financial Studies 10, 481-523.

Jarrow, R.A. and S.M. Turnbull (1995) Pricing derivatives on financial securities subject to credit risk, Journal of Finance 50, 53-85. 
Kahn, C., G. Pennacchi, and B. Sopranzetti (2001) Bank consolidation and consumer loan rates, Wharton Financial Institution Center Working Paper 01-14, Philadelphia, PA.

Kim, K.S. and J.R. Scott (1991) Prediction of corporate failure: An artificial neural network approach, Southwest Missouri State University, Working Paper, September.

Kocagil, A.E., A. Reyngold, and D. Bren (2002) Moody's riskcalc for private companies: Singapore, Moody's Investors Service Global Credit Research, New York, NY.

Longenecker, J.G., C.W. Moore, and J.W. Petty (1997) Credit scoring and the small business: A review and the need for research, Working Paper. Baylor University, Waco, TX.

Merton, R.C. (1974) On the pricing of corporate debt: The risk structure of interest rates, Journal of Finance 29, 449-470.

Mester, L.J. (1997) What's the point of credit scoring?, Federal Reserve Bank of Philadelphia Business Review September/October, 3-16.

Petersen, M. and R. Rajan (2001) Does distance still matter? The information revolution in small business lending, Journal of Finance 57, 2533-2570.

Peterson, M. and R. Rajan (1994) The benefits of lending relationships: Evidence from small business data, Journal of Finance 49, 3-37.

Peterson, M.A. (1999) The small business lending relationship, Conference on Consumer Transactions and Credit. Federal Reserve Bank of Philadelphia, Philadelphia, PA.

Pine, B.J., D. Peppers, and M. Rogers (1995) Do you want to keep your customers forever?, Harvard Business Review March/April, 103-114.

Podding, T. (1994) Bankruptcy prediction: A comparison with discriminant analysis, in A.P. Refenes, ed.: Neural networks in capital markets (John Wiley \& Sons, Ltd., New York).

Rajan, R. and M. Petersen (1995) The effect of credit market competition on lending relationships, Quarterly Journal of Economics 110, 407-443.

Risk Management Association (RMA) (2000) Credit risk capital for retail credit products: A survey of sound practices.

Ronn, E. and A. Verma (1986) Pricing risk-adjusted deposit insurance: An option-based model, Journal of Finance 41, 871-895.

Saunders, A. and L. Allen (2002) Credit risk measurement: New approaches to value at risk and other paradigms, second edition. New York: John Wiley \& Sons.

Scott, J.A. and W.C. Dunkelberg (1999) Bank consolidation and small business lending: A small firm perspective, Conference on Consumer Transactions and Credit. Federal Reserve Bank of Philadelphia, Philadelphia, PA.

Singletary, M. (1995) Keeping score on credit; proponents say test can speed up loan approval, but critics fear quick rejections, The Washington Post December 4, F14.

Staten, M. (2001) The value of comprehensive credit reports: Lessons from the u.S. Experience, Making Small Business Lending Profitable: Proceedings from the Global Conference on Credit Scoring. Global Financial Markets Groups, IFC, Washington, D.C.

Treacy, W.F. and M. Carey (2000) Credit risk rating systems at large u.S. Banks, Journal of Banking and Finance 24, 167-201.

Www.myFICO.com (2003) How do interest rates relate to your score? 
Yang, Z.R., M.B. Platt, and H.D. Platt (1999) Probabilistic neural networks in bankruptcy prediction, Journal of Business Research 67-74.

Zhou, C. (1997) A jump diffusion approach to modeling credit risk and valuing defaultable securities, Working Paper, Federal Reserve Board of Governors.

Zhou, C. (2001) The term structure of credit spreads with jump risk, Journal of Banking and Finance 25, 2015-2040. 